\title{
Oxygen Transfer Ability of Co-Pb Metal Oxides during the Chemical Looping Oxidation of Tuncbilek Lignite
}

\author{
Arzu Kanca ${ }^{1 *}$, Deniz Üner ${ }^{1}$ \\ 1 Orta Doğu Teknik Üniversitesi, Mühendislik Fakültesi, Kimya Mühendisliği Bölümü, Ankara, Türkiye (ORCID: 0000-0001-9110-2691; 0000-0001-8585-3691)
}

(First received 1 January 2020 and in final form 14 March 2020)

(DOI: 10.31590 /ejosat.706923)

ATIF/REFERENCE: Kanca, A. \& Üner, D. (2020). Oxygen Transfer Ability of Co-Pb Metal Oxides during the Chemical Looping Oxidation of Tuncbilek Lignite. European Journal of Science and Technology, (18), 767-778.

\begin{abstract}
The study aims to determine the oxygen transfer ability of cobalt lead $(\mathrm{Co}-\mathrm{Pb})$ mixed oxides during the thermal decomposition of Tuncbilek lignite under inert atmosphere. Thermodynamic calculations of reduction reactions of $\mathrm{Co}-\mathrm{Pb}$ mixed oxides were performed to show the favorable reduction temperatures for the different reductive gases. $\mathrm{Co}$ and $\mathrm{Pb}$ mixed metal oxides were prepared by wet impregnation method and they characterized by X-ray diffractometer and Raman spectroscopy. Oxygen transfer performances of these oxides were evaluated by thermal gravimetric analysis (TGA) in terms of oxidation rates of lignite sample under $\mathrm{N}_{2}$ flows in the range of temperatures between 40 to $600^{\circ} \mathrm{C}$. The results of thermal gravimetric analysis (TGA) indicated that the optimum coal to Co-Pb metal oxides ratio based on oxidation efficiency was 0.11 .
\end{abstract}

Keywords: Chemical looping oxidation, $\mathrm{Co}-\mathrm{Pb}$ metal oxides, Tuncbilek lignite..

\section{Tuncbilek Linyitlerinin Kimyasal Çevrim Oksidasyonu Sırasında Co- Pb Metal Oksitlerin Oksijen Transfer Yetenekleri}

$\ddot{\mathbf{O z}}$

$\mathrm{Bu}$ çalışma, kobalt-kurşun $(\mathrm{Co}-\mathrm{Pb})$ karışık metal oksitlerin Tuncbilek linyitlerininin inert ortamda termal bozunması esnasında göstermiş oldukları oksijen transfer yeteneğini belirlemeyi amaçlamaktadır. Bu metal oksitlerin indirgenme reaksiyonu termodinamik hesaplamaları farklı indirgeyici gazlar için uygun sıcaklıkları belirlemek için yapılmıştır. Co-Pb karışık metal oksitler 1slak emdirme yöntemiyle hazırlanmış ve X-ray kırınımı ve Raman spektrometresi ile karakterize edilmiştir. Bu metal oksitlerin oksijen transfer performansları Termal Gravimetric Analiz (TGA) metoduyla $40-600^{\circ} \mathrm{C}$ sıcaklık aralığında azot atmosferinde gerçekleştirilmiştir. TGA sonuçları optimum linyit/ $\mathrm{Co}-\mathrm{Pb}$ mixed oxide oranının 0.11 olduğunu ortaya koymuştur.

Anahtar Kelimeler: Kimyasal çevrim oksidasyonu,Co-Pb metal oksitler, Tuncbilek linyiti.

\footnotetext{
${ }^{*}$ Corresponding Author (Present Adress): Atatürk Üniversitesi, Mühendislik Fakültesi, Kimya Mühendisliği Bölümü, Erzurum, Türkiye, ORCID: 0000-0001-9110-2691, akanca@,atauni.edu.tr
} 


\section{Introduction}

Chemical looping combustion (CLC) is an alternative technology to solve the economic challenges of $\mathrm{CO}_{2} \mathrm{sequestration} \mathrm{CO}_{2}$ capture is the most expensive part of the thermal power plants in terms of both capital and operating costs. For example, in coal based IGCC systems, $\mathrm{CO}_{2}$ capturing increases the cost of electricity by $25 \%$ (Fan, Li, \& Ramkumar, 2008; Kim et al., 2013). One of the common carbon capture techniques in post-combustion plants is utilization of monoethanolamine (MEA) scrubber. In addition to capital and operating cost, this carbon capture technique decreases the plant efficiency by $10 \%$. In IGCC plants, pre-combustion carbon capture decreases plant efficiency less than MEA, while capital costs are much higher than MEA (Kim et al., 2013).

Unlike these air-combustion based carbon capture technologies, $\mathrm{N}_{2}$-free oxy-combustion technologies make $\sim 100 \%$ carbon capture possible. Air separation unit (ASU), oxygen transport membrane (OTM) and oxygen carrier metals in a chemical looping system are the main alternative $\mathrm{N}_{2}$-free oxygen source systems. Among these resources, ASU increases the cost of the electricity by $45 \%$, while OTM needs high parasitic energy consuming some of the produced energy. Chemical looping system, on the other hand, operates more efficiently and it further allows in-situ $\mathrm{CO}_{2}$ capture without an extra separation unit (Kim et al., 2013). The chemical looping technology has recently gained importance for especially coal based fuel combustion processes.

Different alternative oxygen carrier materials have so far been reported in the literature. Metal oxides commonly used as oxygen carriers are iron, nickel, copper, cobalt, and manganese oxides for the chemical looping combustion technology (Adánez \& Abad, 2019; Cao \& Pan, 2006; Chen et al., 2016; Cho, Mattisson, \& Lyngfelt, 2004; Ksepko, Babinski, Evdou, \& Nalbandian, 2016; Ksepko \& Labojko, 2014; Larring, Braley, Pishahang, Andreassen, \& Bredesen, 2015; Matzen, Pinkerton, Wang, \& Demirel, 2017; R. Siriwardane, Tian, Richards, Simonyi, \& Poston, 2009; R. V. Siriwardane et al., 2013). Fe-Ni bimetallic alloy (Bhavsar \& Veser, 2013), bimetallic $\mathrm{Fe}-\mathrm{Mn}$ on $\mathrm{ZrO}_{2}$, sepiolite, and $\mathrm{Al}_{2} \mathrm{O}_{3}$ (Ksepko, Siriwardane, Tian, Simonyi, \& Sciazko, 2012), and $\mathrm{Cu}, \mathrm{Fe}, \mathrm{Mn}$, or $\mathrm{Ni}$ oxides on $\mathrm{Al}_{2} \mathrm{O}_{3}$, sepiolite $\left(\mathrm{FeTiO}_{3}\right), \mathrm{SiO}_{2}, \mathrm{TiO}_{2}$, and $\mathrm{ZrO}_{2}$ (Adanez et al., 2004; Cho et al., 2004; Ksepko, Siriwardane, Tian, Simonyi, \& Sciazko, 2010; Zafar, Mattisson, \& Gevert, 2005) are the other oxygen carriers.

The main operating steps of the Chemical Looping Combustion (CLC) in terms of MeOx are MeOx reduction in fuel reactor and oxidation of the reduced metal oxide in air reactor (Figure 1). Unlike common coal combustion, there is no direct interaction between the coal and air, thus no nitrogen separation is necessary.

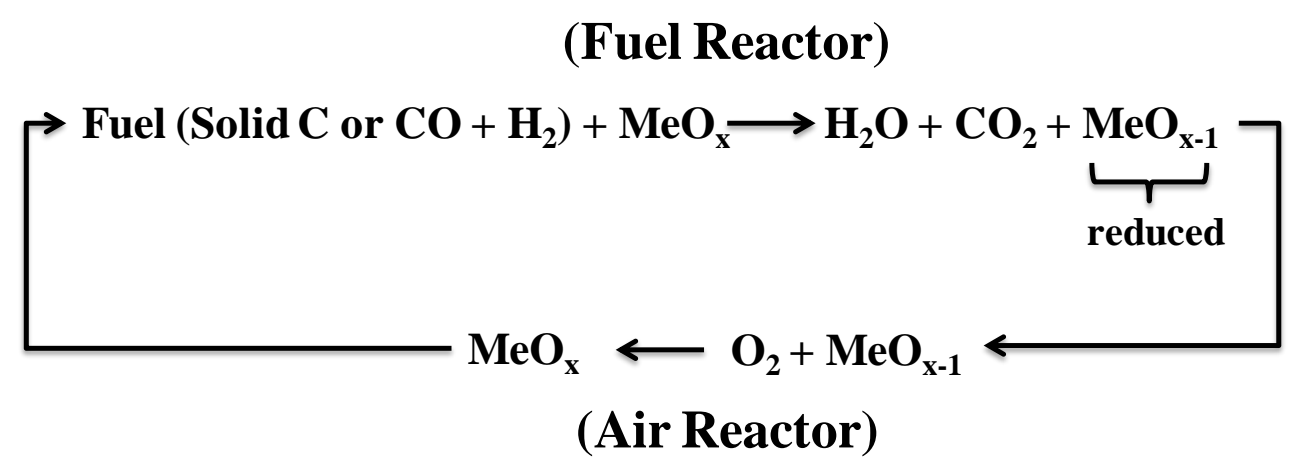

Figure 1. Chemical looping combustion system.

Iron based materials, for example, was examined for coal, petrocoke and char gasification by several researchers due to its low cost, low toxicity and relatively high abundance (Bhavsar \& Veser, 2013; Chen et al., 2016; Jerndal et al., 2011; Ksepko et al., 2016; Larring et al., 2015; Matzen et al., 2017; R. Siriwardane et al., 2009; R. V. Siriwardane et al., 2013; Velasco-Sarria, Forero, AdanezRubio, Abad, \& Adanez, 2018) .

Kim et al.(Kim et al., 2013) listed the possible reactions taking place in the iron oxide based $\left(\mathrm{Fe}_{2} \mathrm{O}_{3}\right)$ reduction reactor as:(Kim et al., 2013)

(i) Devolatilization of coal particles because of the high coal feed temperature,

$$
\text { Coal } \rightarrow \operatorname{Char}(C)_{(s)}+\text { Volatiles }(\mathrm{CxHy})_{(\mathrm{g})}
$$

(ii) Char and $\mathrm{Fe}_{2} \mathrm{O}_{3}$ solid-solid reaction,

$$
2 \mathrm{Fe}_{2} \mathrm{O}_{3(s)}+\operatorname{Char}(\mathrm{C})_{(s)} \rightarrow 4 \mathrm{FeO}_{(s)}+\mathrm{CO}_{2}(g)
$$


(iii) Char gasification,

$$
\begin{gathered}
\operatorname{Char}(C)_{(s)}+\mathrm{CO}_{2(g)} \rightarrow 2 \mathrm{CO}_{(g)} \\
\operatorname{Char}(C)_{(s)}+\mathrm{H}_{2} \mathrm{O}_{(g)} \rightarrow \mathrm{CO}_{(g)}+\mathrm{H}_{2(g)}
\end{gathered}
$$

(iv) $\mathrm{Fe}_{2} \mathrm{O}_{3}$ reduction,

$$
\begin{gathered}
\mathrm{Fe}_{2} \mathrm{O}_{3_{(s)}}+\text { Volatiles }(\mathrm{CxHy})_{(g)} \rightarrow \mathrm{FeO}+\mathrm{CO}_{2} / \mathrm{H}_{2} \mathrm{O} \\
\mathrm{Fe}_{2} \mathrm{O}_{3_{(s)}}+\mathrm{CO} / \mathrm{H}_{2(g)} \rightarrow 2 \mathrm{FeO}_{(s)}+\mathrm{CO}_{2} / \mathrm{H}_{2} \mathrm{O} \\
\mathrm{FeO}_{(s)}+\mathrm{CO} / \mathrm{H}_{2(g)} \rightarrow \mathrm{Fe}_{(s)}+\mathrm{CO}_{2} / \mathrm{H}_{2} \mathrm{O}
\end{gathered}
$$

Solid-solid reaction between the char and $\mathrm{Fe}_{2} \mathrm{O}_{3}$ is the slowest reaction in the reduction part of the reactor. In this system, $\mathrm{CO}_{2}$ and $\mathrm{H}_{2} \mathrm{O}$ are initially introduced to the system to increase the carbon conversion. After these gases $\left(\mathrm{CO}_{2}\right.$ and $\left.\mathrm{H}_{2} \mathrm{O}\right)$ are reduced to $\mathrm{CO}$ and $\mathrm{H}_{2}$ during char gasification, they are oxidized again by the oxygen carrier, iron oxide (Kim et al., 2013).

The main heuristics of the CLC system are based on the selection of suitable metal oxides. The metal oxides must have high oxygen exchange potential, high resistance against the abrasion, high and stable reactivity, and tolerated interaction with coal inorganics. The circulation of the high amount of ash and appropriate reactor design are mechanistic drawbacks about the CLC systems (Larring et al., 2015; R. Siriwardane et al., 2009; Zafar et al., 2005).

Despite the numerous reports on different chemical looping agents, in this section a brief review on the literature presenting results for $\mathrm{Co}$ and $\mathrm{Fe}$ based compounds. Siriwardane et al.(R. Siriwardane et al., 2009) tested the oxygen transfer abilities of $\mathrm{CuO}_{2} \mathrm{Fe}_{2} \mathrm{O}_{3}$, $\mathrm{Mn}_{2} \mathrm{O}_{3}$, and $\mathrm{Co}_{3} \mathrm{O}_{4}$ in the presence of $\mathrm{N}_{2}$ and/or $\mathrm{CO}_{2}$. They followed the interaction between the ash and metal oxide by thermodynamic calculations and XRD. Furthermore, reaction rates and combustion to oxidation ratio were investigated by TGA and in a fixed-bed reactor system. They found that the oxides of $\mathrm{CuO}, \mathrm{Fe}_{2} \mathrm{O}_{3}, \mathrm{Mn}_{2} \mathrm{O}_{3}$, and $\mathrm{Co}_{3} \mathrm{O}_{4}$ have permanent oxidation ability at $700-1000^{\circ} \mathrm{C}$. The best oxidation and reduction performance for $\mathrm{CuO}$ was obtained during the chemical looping combustion of coal in the temperature range between $500^{\circ} \mathrm{C}$ to $700^{\circ} \mathrm{C}$. Low melting point of $\mathrm{CuO}$ makes coal chemical looping possible at low temperatures (R. Siriwardane et al., 2009).

Cao and Pan (Cao \& Pan, 2006) investigated Ni, Co, Cu, and Mn oxides, for CLC of solid fuels. Among them, Mn-based oxygen carrier showed a very poor performance because of its low oxygen exchange potential, high reduction endothermicity, and its thermodynamic limitation on $\mathrm{CO}_{2}$ purification due to the low $\mathrm{CO}_{2}$ partial pressure. The rest, on the other hand, showed good reduction performances. The best oxidation performance was recorded for $\mathrm{CoO}$ in this study. Two applications were mentioned in this study. In the first process, solid fuels were gasified initially by pure $\mathrm{O}_{2}$ in the gasifier, gaseous products $\left(\mathrm{CH}_{4}, \mathrm{CO}\right.$, and $\left.\mathrm{H}_{2}\right)$ were sent to the CLC system. Since utilization of the gasifier increases the capital cost, Cao and Pan considered that solid fuel could be sent to the CLC system without any pre-processes. Thus, both solid fuel and syngas oxidation took place in the fuel reactor. The main drawback of this approach was described as the low reaction yields due to the low solid-solid interaction between metal oxide and solid fuels, owing to lower reaction kinetics of gasification than combustion (Cao \& Pan, 2006).

In another study, Cho et al.(Cho et al., 2004) used $\mathrm{Al}_{2} \mathrm{O}_{3}$-supported $\mathrm{Ni}, \mathrm{Cu}$ and $\mathrm{Fe}$ oxides as oxygen carriers for CLC system. The reactivity of $\mathrm{Ni}$ and $\mathrm{Cu}$ oxides was found to be higher than $\mathrm{Fe}$ oxide. The highest reduction rate was recorded for NiO, while low mechanical strength was the challenge for this metal oxide. Additionally, since agglomeration is the main challenge for $\mathrm{Al}_{2} \mathrm{O}_{3}$-supported $\mathrm{Cu}$ and Fe based oxygen carriers, these metal oxides were found not to be appropriate oxygen carriers (Cho et al., 2004).

At that point cobalt and lead can be considered as alternative oxygen carrier materials. Cobalt and lead based mixed oxide were employed as catalysts for soot oxidation (Genc, Altay, \& Uner, 2005; Uner, Demirkol, \& Dernaika, 2005). Uner et al.(Uner et al., 2005) showed that lead oxides improve the contact between soot and catalyst by forming a molten phase and these oxides could donate oxygen atoms rather easily. Differential Scanning Calorimeter (DSC) thermograms obtained for pure lead oxide and $\mathrm{Co}-\mathrm{Pb}$ mixed oxides proved the eutectic mixture formation of $\mathrm{Co}$ and $\mathrm{Pb}$ as well as molten phase formation. Temperature programmed oxidation (TPO) experiments were performed to test the Diesel soot oxidation activity of $\mathrm{CoOx}, \mathrm{PbOx}$, and $\mathrm{Co}-\mathrm{Pb}$ mixed oxides. The decrease in peak temperature of $\mathrm{CO}_{2}$ formation and the increase in reaction rate were observed in the presence of $\mathrm{PbOx} . \mathrm{CO}_{2}$ and $\mathrm{CO}$ evolution during TPO experiments carried out in inert atmosphere indicated the utilization of catalyst lattice oxygen (Uner et al., 2005). The catalysts were also tested on-board after being coated on a diesel soot filter and mounted after the exhaust line of a Diesel engine (Genc et al., 2005). The similarity between balance point temperature of on-board tests and peak temperature of laboratory reactor tests confirmed that $\mathrm{CoPbOx}$ catalyst are more efficient than CoOx catalysts. Genc et al.(Genc et al., 2005) concluded that $\mathrm{Pb}$ mobility caused by formation of the molten phase at some points of the filter increased the catalytic activity for diesel soot oxidation. In conclusion, $\mathrm{Co}-\mathrm{Pb}$ mixed metal oxides can be used as both oxygen carrier and catalyst due to their high oxygen exchange potential (Genc et al., 2005; Uner et al., 2005). Sarafraz et al. (Sarafraz, Jafarian, Arjomandi, \& Nathan, 2018) reported that molten lead is thermodynamically realistic for the e-ISSN: 2148-2683 
chemical looping syngas production process. They found the molten lead could be a potential oxygen carrier for the steam and/or $\mathrm{CO}_{2}$ gasification of solid feedstocks (Sarafraz et al., 2018).

The aim of this study was to develop a fundamental understanding of the oxygen transfer ability of $\mathrm{Co}-\mathrm{Pb}$ mixed metal oxides during the lignite thermal decomposition. A thermodynamic analysis of the redox capabilities of these metal oxide indicated superior performance for direct carbon and syngas chemical looping systems. Thermodynamic calculations of the oxidation and reduction reactions were used to compare the operating temperatures of these types of metal oxides with others. TGA experiments at various coal to $\mathrm{Co}-\mathrm{Pb}$ metal oxide ratios under inert atmosphere were performed in order to investigate the lattice oxygen utilization.

\section{Material and Method}

\subsection{Preparation and Characterization of Coal Sample}

Coal samples were obtained from Turkish Coal Enterprises (TKI) Tuncbilek Lignite Establishment in Turkey. The details of sample preparation and characterization were explained in our previous papers (Kanca, Dodd, Reimer, \& Uner, 2016; Kanca \& Uner, 2019).

\subsection{Preparation and Characterization of $\mathrm{Co}-\mathrm{Pb}$ Individual and Mixed Metal Oxides}

\subsubsection{Preparation of Co-Pb Individual and Mixed Metal Oxides}

$\mathrm{Co}-\mathrm{Pb}$ metal oxide was prepared by incipient wetness method impregnation of $\mathrm{C}_{4} \mathrm{H}_{6} \mathrm{O}_{4} \mathrm{~Pb}_{3} 3 \mathrm{H}_{2} \mathrm{O}$ (54.6\% wt $\mathrm{Pb}$, Merck) aqueous solution on $\mathrm{CoOx}(90.8 \%$ wt $\mathrm{Co}$, Ege Ferro) powder for a final oxide having a $\mathrm{Co} / \mathrm{Pb}$ ratio of $1 / 1$ by weight. In order to achieve this, the metal precursors were stirred in water for 3 hours. The mixture was dried overnight at $105^{\circ} \mathrm{C}$ and then it was calcined at $450^{\circ} \mathrm{C}$ for 4 hours. In addition to the mixed oxides prepared as such, commercial PbO (Sigma-Aldrich) and calcined Co powder (Ege Ferro) as received from the vendor were used during pyrolysis and oxidation experiments.

\subsubsection{Characterization of Co-Pb Individual and Mixed Metal Oxides}

XRD patterns were measured on a Philips model PW1840 (1729) X-ray diffractometer using Ni filtered Cu-Ka 945 radiation at a scan rate of 0.05 degrees/s. Raman spectra were obtained from a Bruker IFS 66/S, FRA 106/S, HYPERION 1000, RAMANSCOPE II. $1064 \mathrm{~nm}$ nd-YAG laser was used in Raman Spectroscopy. Shimadzu AA-6300 Atomic Absorption Spectrophotometer was employed to determine the elemental composition of $\mathrm{Co}$ and $\mathrm{Pb}$. AAS was performed by dissolving $0.25 \mathrm{~g}$ solid sample in the acid mixture involving

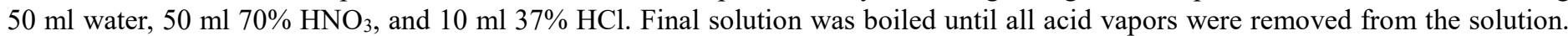
After dilution with $30 \mathrm{ml}$ distilled water, solution was boiled for $30 \mathrm{~min}$. The solution was cooled and diluted to appropriate concentration by distillated water. Concentration of the sample was determined after the calibration of reference solutions. $1 / 1 \mathrm{Co}$ to $\mathrm{Pb}$ ratio of the final mixture was confirmed from AAS as 1.

\subsection{Reaction Test}

Thermal Gravimetric Analysis (TGA) (Shimadzu DTG 60H) experiments were conducted at a temperature between $25^{\circ} \mathrm{C}$ and $600^{\circ} \mathrm{C}$ with a heating rate of $10^{\circ} \mathrm{C} / \mathrm{min}$ under $75 \mathrm{cc} / \mathrm{min} \mathrm{N}_{2}$ flow for pyrolysis process in order to show the effect of different $\mathrm{Co}-\mathrm{Pb}$ metal oxide addition on the weight loss in the lignite samples.

\section{Results and Discussion}

\subsection{Oxidation and Reduction Thermodynamics of Co-Pb Metal Oxides}

The standard Gibbs free energy values of oxidation and reduction reactions of $\mathrm{Co}-\mathrm{Pb}$ metal oxides were calculated as a function of temperature. The standard Gibbs free energies of formation data for components at different temperatures were obtained from the literature (Barin, 1989) and the standard free energy change of the reaction was determined according to the equation given below:

$$
\Delta \mathrm{G}_{\mathrm{rxn}}^{\mathrm{o}}=\sum_{\text {products }} v_{\mathrm{i}} \Delta \mathrm{G}^{\mathrm{f}}-\sum_{\text {reactants }} v_{\mathrm{i}} \Delta \mathrm{G}^{\mathrm{f}}
$$

Figure 2 indicates the free energy changes of redox reactions in the presence of different reducing agents. The comparison was based on per mole of $\mathrm{O}_{2}$. When the temperature is higher than $970 \mathrm{~K}$, the most favorable reaction is the partial oxidation of carbon with $\mathrm{PbO}$, while the best reducing agent is carbon monoxide when the temperature is less than $970 \mathrm{~K}$. Additionally, the minimum temperature for the favorable for the partial oxidation of carbon is $570 \mathrm{~K}$. These reduction behaviors are compatible with the oxidation reactions. 


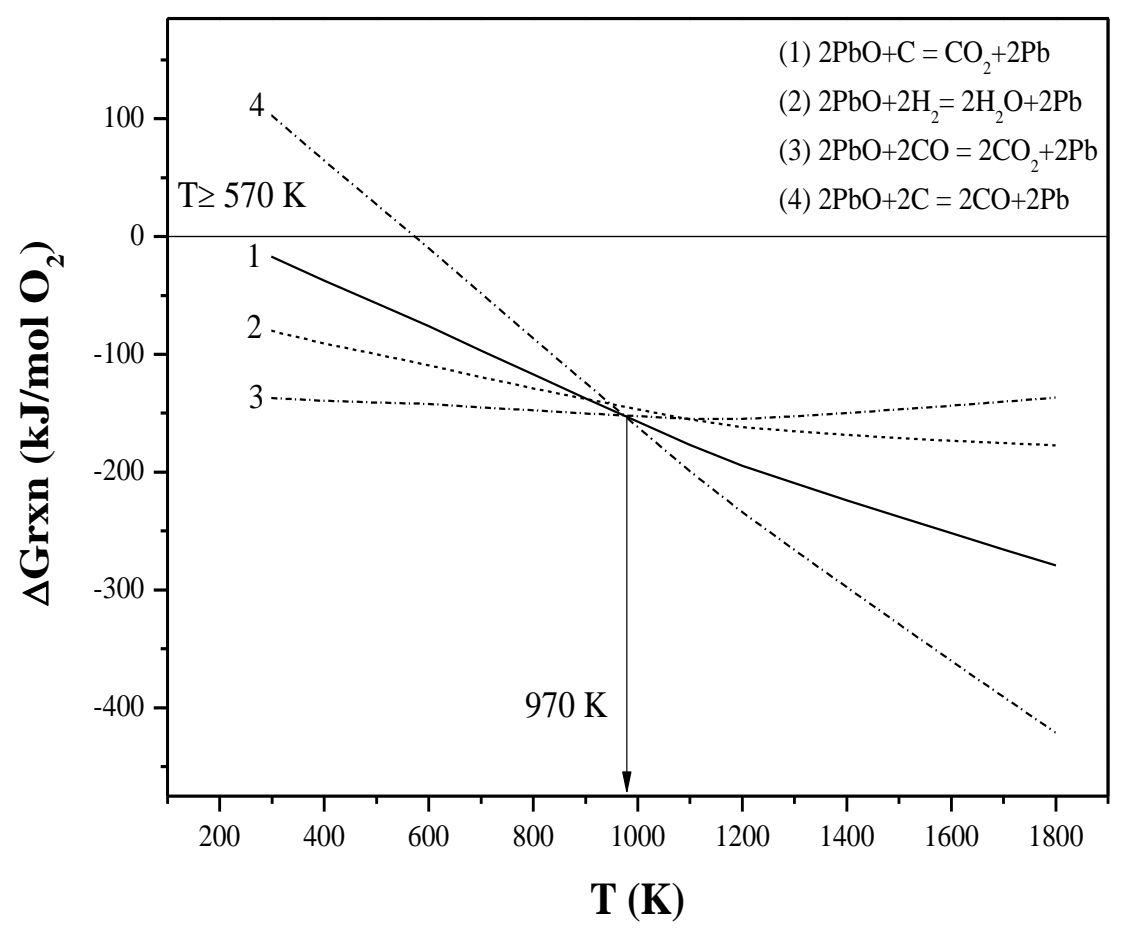

Figure 2. Standard Gibbs free energy change during lead oxide reduction.

The redox reactions of $\mathrm{CoO}$ with $\mathrm{H}_{2}$ and $\mathrm{CO}$ are shown in Figure 3. Similar to $\mathrm{PbO}$, when the temperature is lower than $977 \mathrm{~K}$, the most favorable reaction is $\mathrm{PbO}$ reduction reaction with $\mathrm{CO}$. On the other hand, when the temperature is higher than $977 \mathrm{~K}$, the most favorable reaction is carbon partial oxidation reaction.

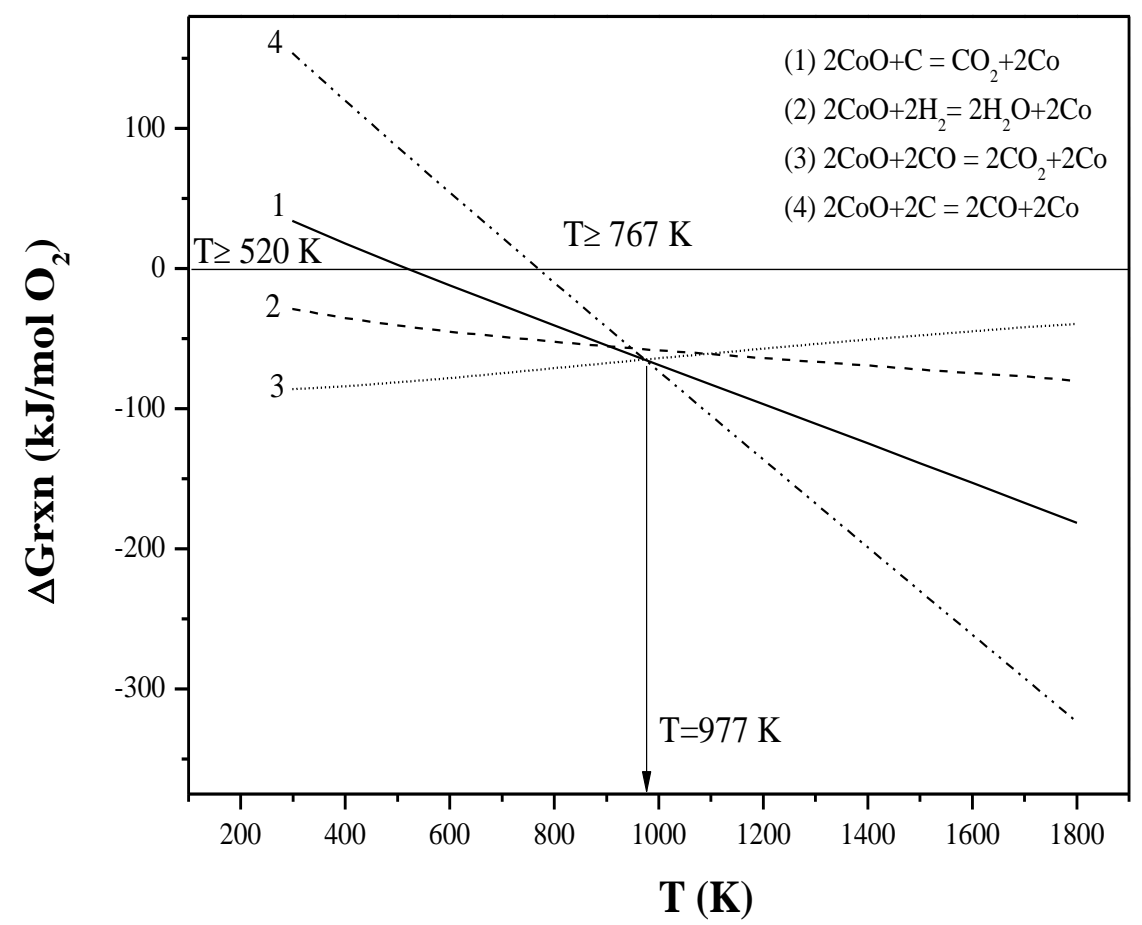

Figure 3. Standard Gibbs free energy change during cobalt oxide reduction. 
When the reduction thermodynamics of $\mathrm{CoO}$ and $\mathrm{PbO}$ were compared, it was found that $\mathrm{PbO}$ can give its oxygen to both $\mathrm{H}_{2}$ and $\mathrm{C}$ easier than $\mathrm{CoO}$. Gibbs free energy of reduction reactions are lower for $\mathrm{Pb}$ oxide than $\mathrm{Co}$ oxide. As a result, in order to determine the mixed oxides behavior, TGA experiments under inert atmosphere were carried out.

\subsection{Characterization of $\mathrm{Co}-\mathrm{Pb}$ Metal Oxides}

\subsubsection{XRD Pattern of Co-Pb Metal Oxide}

Possible oxide formations of $\mathrm{Pb}$ and $\mathrm{Co}$ such as $\mathrm{PbO}, \mathrm{PbO}_{2}, \mathrm{~Pb}_{3} \mathrm{O}_{4}$, and $\mathrm{Pb}_{2} \mathrm{O}_{3}, \mathrm{CoO}, \mathrm{Co}_{2} \mathrm{O}_{3}$ and $\mathrm{Co}_{3} \mathrm{O}_{4}$ were checked within the $\mathrm{XRD}$ databank (Data). $\mathrm{PbO}$ was determined as the only $\mathrm{Pb}$ oxide form while the oxide form of $\mathrm{Co}$ was determined to be $\mathrm{Co}_{3} \mathrm{O}_{4}$. According to XRD databank, the Bragg angle values of $\mathrm{PbO}$ are defined at around $28.84^{\circ}, 35.97^{\circ}, 48.76^{\circ}, 49.46^{\circ}, 55.04^{\circ}$. The specific $\mathrm{Co}_{3} \mathrm{O}_{4}$ peak values were also monitored as approximately, $31.43^{\circ}, 37.02^{\circ}, 45.06^{\circ}, 59.51^{\circ}$, and $65.39^{\circ}$ in JPDC cards (Data). Specific Bragg angle values of $\mathrm{PbO}$ and $\mathrm{Co}_{3} \mathrm{O}_{4}$ are presented in Figure 4. When these two metal oxides were mixed, additional peak formation was observed except for individual $\mathrm{PbO}$ and $\mathrm{Co}_{3} \mathrm{O}_{4}$. These additional peaks were not identified but they can be interpreted as alloys of lead and cobalt and their mixed oxides.

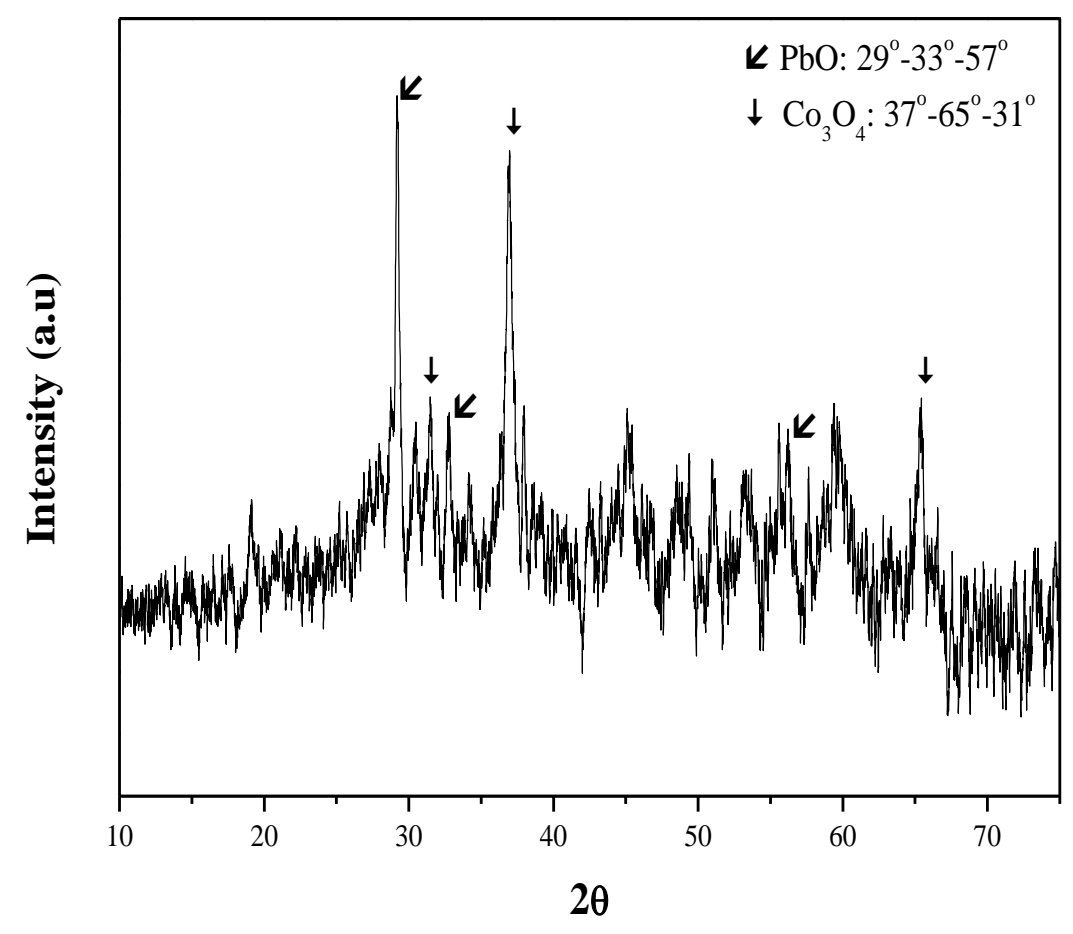

Figure 4. XRD pattern of $\mathrm{Co}-\mathrm{Pb}$ mixed oxides with $\mathrm{Co} / \mathrm{Pb}$ ratio of $1 / 1$.

\subsubsection{Raman Spectra of Co-Pb Metal Oxide}

Raman spectrum of $\mathrm{Co}-\mathrm{Pb}$ metal oxide is presented in Figure 5. The oxidation states of these metals are labeled on each peak. The characteristic Raman spectrum of $\mathrm{Co}_{3} \mathrm{O}_{4}$ revealed peaks at around 196, 486, 524, 620 and $697 \mathrm{~cm}^{-1}$ (Lopes, El Hassan, Guerba, Wallez, \& Davidson, 2006; Shen, Miao, Zhao, \& Xu, 2008; Yung, Zhao, Woods, \& Ozkan, 2008). The experimental frequency values for the $\mathrm{Pb}$ oxide formation were reported as $\mathrm{Pb}-\mathrm{O}-\mathrm{Pb}$ bend $124 \mathrm{~cm}^{-1}, \mathrm{~Pb}-\mathrm{O}$ stretch 386, 365, $290 \mathrm{~cm}^{-1}$ (Jensen, 2003). Raman spectrum of Co$\mathrm{Pb}$ metal oxide reveal two geometrical structures for $\mathrm{PbO}$; tetragonal litharge $\alpha-\mathrm{PbO}$ at $145 \mathrm{~cm}^{-1}$ and orthorhombic massicot $\beta-\mathrm{PbO}$ in $290 \mathrm{~cm}^{-1}$ wavenumber (Jensen, 2003). The characteristic Raman bands of $\mathrm{PbO}$ and $\mathrm{Co}_{3} \mathrm{O}_{4}$ obtained from the literature are collected in Table 1. 


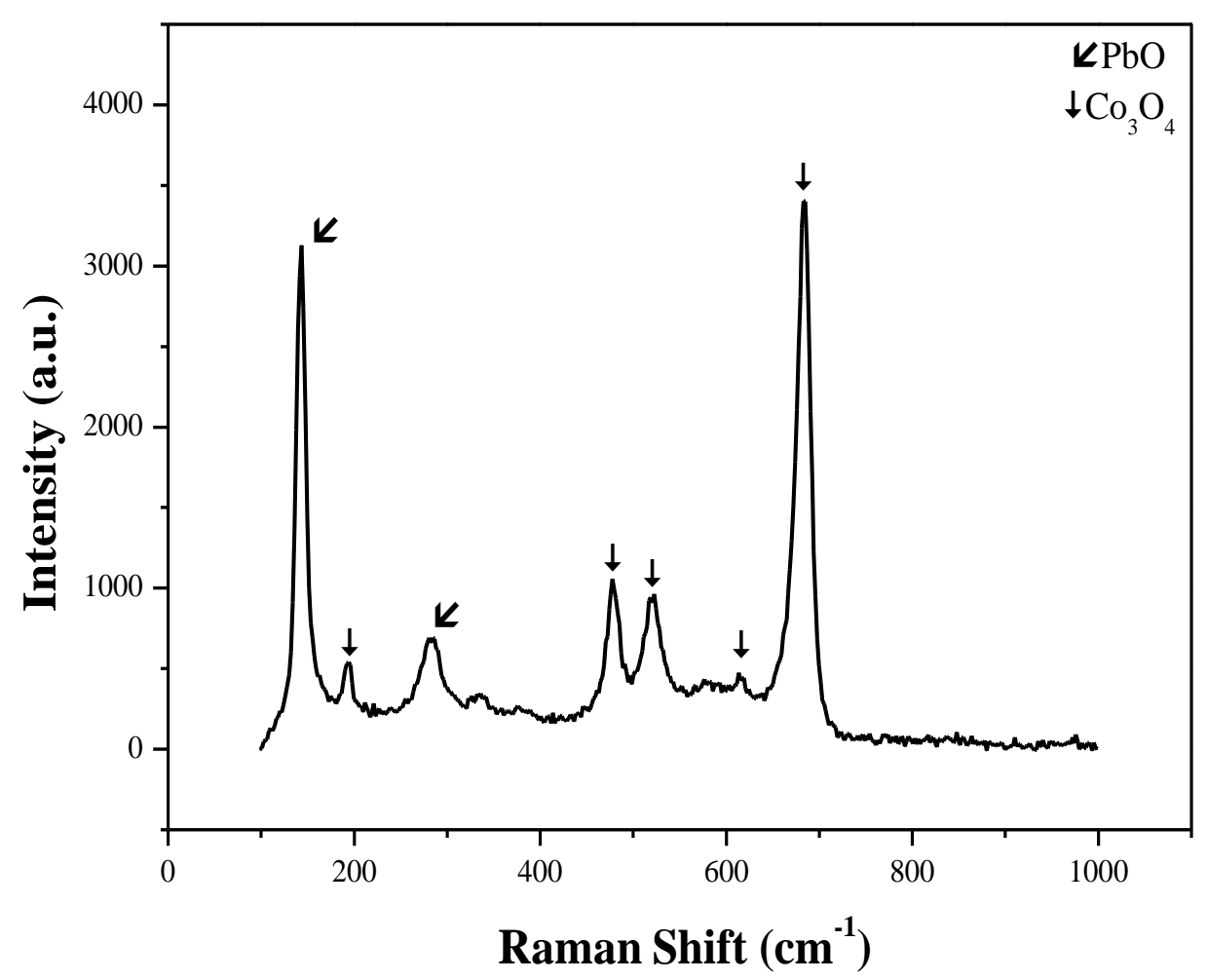

Figure 5. Raman spectrum of Co-Pb mixed oxide with $\mathrm{Co} / \mathrm{Pb}$ ratio of 1/1.

Table 1. Characteristic Raman shifts of $\mathrm{Co}_{3} \mathrm{O}_{4}$ and $\mathrm{PbO}$.

\begin{tabular}{|c|c|}
\hline Types of oxides & Raman Shifts $\left(\mathbf{c m}^{-1}\right)$ \\
\hline $\mathrm{Co}_{3} \mathrm{O}_{4}$ & $196,486,524,620,695$ \\
\hline $\mathrm{PbO}$ & 145 for $\alpha$-PbO and 285 for $\beta-\mathrm{PbO}$ \\
\hline
\end{tabular}

In conclusion, $\mathrm{PbO}$ and $\mathrm{Co}_{3} \mathrm{O}_{4}$ formations determined by $\mathrm{XRD}$, were also confirmed by Raman spectroscopy.

\subsection{TGA Experiments under Inert Atmosphere in the Absence and Presence of $\mathrm{Co}-\mathrm{Pb}$ Metal Oxides}

The coal-metal oxide mixtures were studied with TGA under inert atmosphere in order to determine the oxygen release ability of the mixed oxides. As seen from the derivative TGA curves shown in Figure 6, the peak oxidation temperatures of high loading (10/2) coal $/ \mathrm{Co}-\mathrm{Pb}$ oxides are around $100^{\circ} \mathrm{C}$ higher than low loading $(1$ and 0.25$)$ coal/Co-Pb oxides. When coal to metal oxides ratio is higher than 2 (Figure $6 \mathrm{a}$ ), only one peak is observed around $450^{\circ} \mathrm{C}$. On the other hand, when the ratio of coal to Co-Pb metal oxides is less than 1 (Figure $6 \mathrm{~b}$ ), two distinct peaks are observed in the temperature range of $280-320^{\circ} \mathrm{C}$, with a minor component left at around $450^{\circ} \mathrm{C}$. The derivative TGA curve of the mixed oxides in the absence of coal also exhibit a weight loss peaking around $330^{\circ} \mathrm{C}$, correlating nicely with the peaks in this temperature range. 

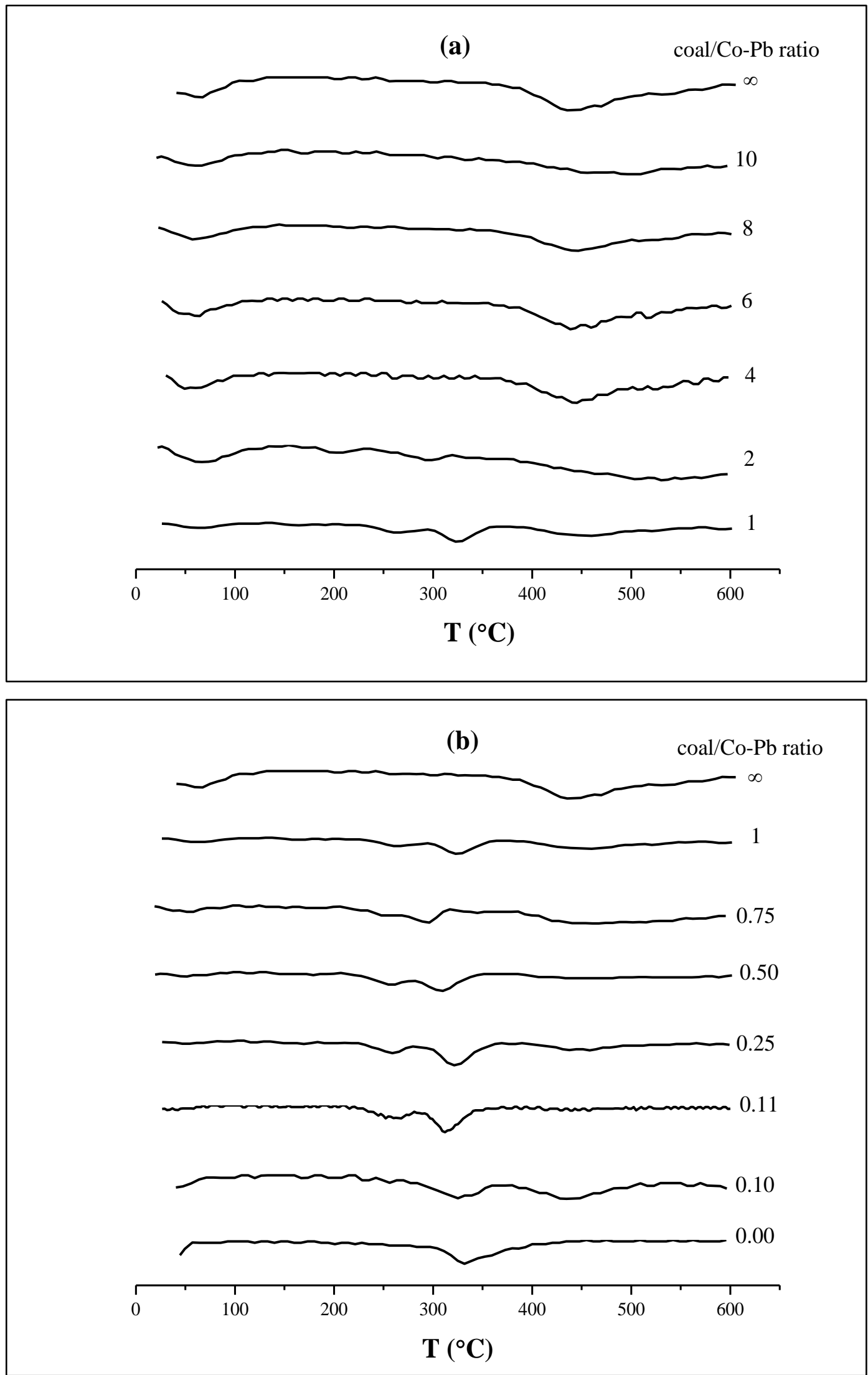

Figure 6. TGA pyrolysis thermograms of lignite in the presence of different metal oxide contents.

The results of TGA analysis of Tuncbilek lignite in the absence and the presence of $\mathrm{Co}-\mathrm{Pb}$ metal oxides were presented in Table 2 as the average values of two identical experiments. The final $\mathrm{Co}-\mathrm{Pb}$ metal oxide has a $\mathrm{Co} / \mathrm{Pb}$ ratio of $1 / 1$ by weight and the relative amount of $\mathrm{O}_{2}$ in the $\mathrm{Co}-\mathrm{Pb}$ metal oxide was taken to be about $18 \%$ as will be shown below. Both TGA experiments under $\mathrm{N}_{2}$ and air 
flow and classical proximate analysis revealed that Tuncbilek lignite has approximately $28 \%$ volatiles and $38 \%$ ash. $60.5 \%$ weight loss was recorded during TGA under air flow. This weight loss was attributed to the combustible materials in coal structure (Kanca, 2013; Kanca et al., 2016). Approximately 3\% moisture present in the coal sample was not taken specifically into account in these calculations, introducing $3 \%$ error in weight estimations associated with the moisture.

Table 2. Material balance in the absence and presence of Co-Pb metal oxides.

\begin{tabular}{|c|c|c|c|c|c|c|c|c|c|c|}
\hline $\begin{array}{l}\text { Sample } \\
(\mathrm{Coal} / \mathrm{Co}- \\
\mathrm{Pb})\end{array}$ & $\begin{array}{l}\text { Initial } \\
\text { amount } \\
\text { of } \\
\text { sample } \\
\text { (mg) }\end{array}$ & $\begin{array}{l}\text { Amount } \\
\text { of coal } \\
\text { in the } \\
\text { sample } \\
(\mathrm{mg})\end{array}$ & $\begin{array}{l}\text { Amount } \\
\text { of oxide } \\
\text { in the } \\
\text { sample } \\
(\mathrm{mg})\end{array}$ & $\begin{array}{l}\text { Amount } \\
\text { of } \\
\text { volatiles } \\
\text { in the } \\
\text { sample } \\
\text { includin } \\
\mathrm{g} \\
\text { moisture } \\
(28 \% \text { of } \\
\text { coal) } \\
(\mathrm{mg})\end{array}$ & $\begin{array}{l}\text { Amount } \\
\text { of } \\
\text { availabl } \\
\text { e } \\
\text { oxygen } \\
\text { from } \\
\text { Co-Pb } \\
\text { oxides } \\
\text { (mg) }\end{array}$ & $\begin{array}{l}\text { Amount } \\
\text { of non } \\
\text { volatile } \\
\text { carbon } \\
(\mathrm{mg})\end{array}$ & $\begin{array}{l}\text { Total } \\
\text { weight } \\
\text { loss } \\
\text { measure } \\
\text { d (mg) }\end{array}$ & $\begin{array}{l}\text { Total } \\
\text { weight } \\
\text { loss } \\
\text { measured } \\
(\%)\end{array}$ & $\begin{array}{l}\text { Expected } \\
\% \text { weight } \\
\text { loss } \\
\text { volatiles } \\
\text { only }(\%)\end{array}$ & $\begin{array}{l}\text { Expected } \\
\% \text { weight } \\
\text { loss of } \\
\text { volatiles+ } \\
\text { oxygen } \\
(\%)\end{array}$ \\
\hline$\infty$ & 15.43 & 15.43 & 0.00 & 4.32 & 0.00 & 5.02 & 4.32 & 28.00 & 28.00 & 28.00 \\
\hline 10 & 13.49 & 12.26 & 1.23 & 3.43 & 0.22 & 3.99 & 3.86 & 28.6 & 25.43 & 27.06 \\
\hline 8 & 15.69 & 13.95 & 1.74 & 3.91 & 0.31 & 4.53 & 3.67 & 23.37 & 24.92 & 26.9 \\
\hline 1 & 20.40 & 10.20 & 10.20 & 2.86 & 1.84 & 3.31 & 4.07 & 19.95 & 14.02 & 23.04 \\
\hline 0.75 & 17.78 & 7.62 & 10.16 & 2.13 & 1.83 & 2.48 & 4.04 & 22.69 & 11.98 & 22.27 \\
\hline 0.5 & 21.93 & 7.31 & 14.62 & 2.05 & 2.63 & 2.37 & 4.01 & 18.28 & 9.35 & 21.34 \\
\hline 0.25 & 22.35 & 4.47 & 17.88 & 1.25 & 3.22 & 1.45 & 4.23 & 18.93 & 5.59 & 20.00 \\
\hline 0.11 & 30.90 & 3.06 & 27.84 & 0.86 & 5.01 & 0.99 & 4.54 & 14.70 & 2.78 & 19.00 \\
\hline 0.1 & 24.27 & 2.21 & 22.06 & 0.62 & 3.97 & 0.72 & 1.90 & 7.83 & 2.55 & 18.91 \\
\hline 0 & 43.94 & 0.00 & 43.94 & 0.00 & 7.91 & 0.00 & 1.33 & 3.02 & 0.00 & 17.99 \\
\hline
\end{tabular}

In Table 2, the TGA results and the material balance comparison of the results were presented. The material balance was carried out as follows:

1. The amount of volatiles were determined from the TGA data of the pure coal as $28 \%$ of the coal weight.

2. The available oxygen in the sample was assumed to be $18 \%$ of the total weight of the available oxides. This assumption is based on the results of XRD, Raman, and Atomic absorption spectroscopy. XRD and Raman spectroscopy revealed that the oxidation states of $\mathrm{Pb}$ and $\mathrm{Co}$ are in the form of $\mathrm{PbO}$ and $\mathrm{Co}_{3} \mathrm{O}_{4}$, respectively. Furthermore, $\mathrm{Co} / \mathrm{Pb}$ ratio of the final mixture was obtained from $\mathrm{AAS}$ as 1 . On the basis of $1 \mathrm{~g} \mathrm{Co}$ and $1 \mathrm{~g} \mathrm{~Pb}$

$$
\begin{gathered}
\frac{16 \mathrm{~g} \mathrm{O}_{2}}{207.2 \mathrm{gPb}} \times 1 \mathrm{gPb}+\frac{64 \mathrm{~g} \mathrm{O}_{2}}{3 \times 58.9 \mathrm{gCo}} \times 1 \mathrm{gCo}=0.44 \mathrm{gO}_{2} \\
y_{\mathrm{O} 2}=\frac{0.44 \mathrm{~g} \mathrm{O}_{2}}{2.44 \mathrm{~g}\left(\mathrm{PbO}+\mathrm{CO}_{3} \mathrm{O}_{4}\right)}=0.18
\end{gathered}
$$

3. The weight loss due to volatiles only and oxygen only were determined as described above. The corresponding \% loss was also determined and tabulated.

As can be seen from the comparison of the estimation from the material balance reported in the column of expected \% weight loss volatiles only (\%) with its corresponding experimental value, the estimations are satisfactory despite the extensive assumptions listed above. At high coal/metal oxide ratios the majority of the weight loss is due to the volatiles. When coal/metal oxide ratios decrease below 1, the peak temperatures shift below $350^{\circ} \mathrm{C}$ and two peaks indicating two processes prevail in the derivative TGA curves. The material balances become comparable after coal/metal oxide ratios of 0.11 , where the oxygen stoichiometry becomes consistent with the oxygen demands of the fuel available in the sample. The behavior of the sample with coal $/$ metal oxide ratio $=0.1 \mathrm{resembles}$ a superposition of the pure coal data and pure mixed metal oxide data indicating poor mixing. 
In Figure 7, the experimental weight loss with the estimated weight loss for two different situations was compared. In the figure, symbols represent the experimental data, solid line represents the prediction for the loss of volatiles only and the dashed line represent the prediction for the loss of volatiles and total available oxygen in the sample.

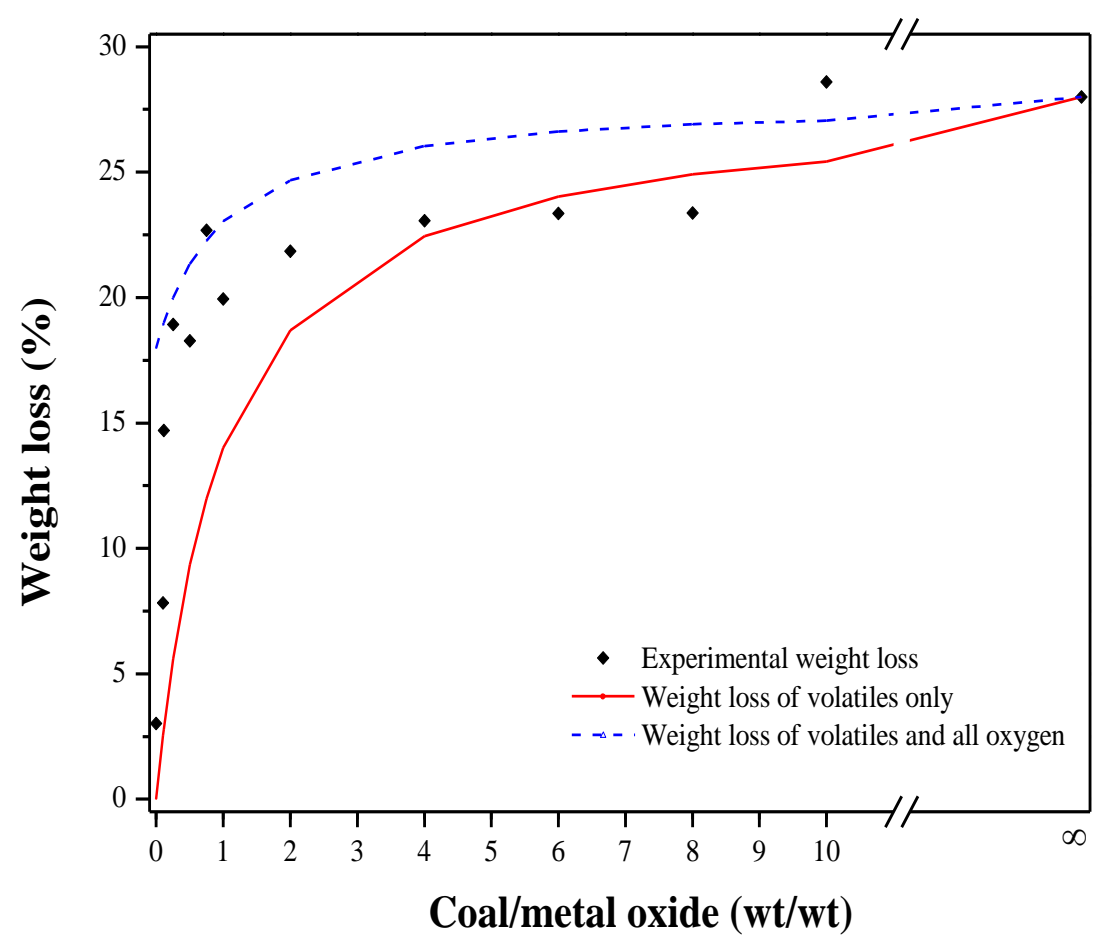

Figure 7. Estimated and experimental weight loss vs coal/Co-Pb mixed oxide ratio.

As the coal/catalyst ratio decreases, experimental data (filled diamonds) and the predictions of material balance for the volatiles (solid line) agree very well indicating that at these ratios, oxygen is not participating in the combustion and only volatiles are lost, consistent with the derivative curve of TGA: there is only one peak at around $450^{\circ} \mathrm{C}$ for samples with coal/oxide ratio $\geq 4$. As the amount of oxide in the sample is increased, i.e. decreasing coal/oxide ratios below 2, the experimental weight loss becomes greater than the weight loss predicted by only through the loss of volatiles. When the disappearance of all of the oxygen coming through the oxide is included in the material balance, the curve represented by a dashed line is obtained. As can be seen from the figure, this curve over predicts the weight loss. We have to mention that this simple analysis overlooks the possibility of sample to sample differences due to the heterogeneity of the solids. The heterogeneous nature of the coal and the differences in the oxidation states of the oxides can easily bring about $10 \%(\mathrm{wt} / \mathrm{wt})$ sample-to-sample difference.

\section{Conclusions and Recommendations}

The reduction thermodynamics of $\mathrm{CoO}$ and $\mathrm{PbO}$ indicates that $\mathrm{PbO}$ can give its oxygen to both $\mathrm{H}_{2}$ and $\mathrm{C}$ easier than $\mathrm{CoO}$. $\mathrm{As}$ determined from thermal gravimetric analysis experiments, in the presence of $\mathrm{Co}-\mathrm{Pb}$ mixed metal oxides, the peak oxidation temperature of Tuncbilek lignite decrease from $450^{\circ} \mathrm{C}$ to $320^{\circ} \mathrm{C}$ in $\mathrm{N}_{2}$ atmosphere. Under $\mathrm{N}_{2}$ flow, the variation of oxidation products with metal oxide amount reveals that the lattice oxygen of the $\mathrm{Co}-\mathrm{Pb}$ mixed metal oxides is used in the oxidation process. The XRD and Raman results clearly indicate that $\mathrm{Co}$ and $\mathrm{Pb}$ are present in the oxide form of $\mathrm{Co}_{3} \mathrm{O}_{4}$ and $\mathrm{PbO}$.

\section{Acknowledgements}

The authors are grateful for Turkish Coal Enterprises for coal samples and partial financial support for this project. Arzu Kanca is supported by the State Planning Organization under the auspices of BAP-08-11-DPT-2002K120510 OYP program. Thank to Atatürk University for permission to her OYP-PhD program at METU. Management and staff of METU Central Laboratory and Mihrican Açıkgöz are kindly acknowledged for their support and service. 


\section{References}

Adánez, J., \& Abad, A. (2019). Chemical-looping combustion: Status and research needs. Proceedings of the Combustion Institute, 37(4), 4303-4317. doi:https://doi.org/10.1016/j.proci.2018.09.002

Adanez, J., de Diego, L. F., Garcia-Labiano, F., Gayan, P., Abad, A., \& Palacios, J. M. (2004). Selection of oxygen carriers for chemicallooping combustion. Energy \& Fuels, 18(2), 371-377. doi:10.1021/ef0301452

Barin, I. (Ed.) (1989). Thermochemical data of pure substances.

Bhavsar, S., \& Veser, G. (2013). Bimetallic Fe-Ni Oxygen Carriers for Chemical Looping Combustion. Industrial \& Engineering Chemistry Research, 52(44), 15342-15352. doi:10.1021/ie400612g

Cao, Y., \& Pan, W. P. (2006). Investigation of chemical looping combustion by solid fuels. 1. Process analysis. Energy \& Fuels, 20(5), 1836-1844. doi:10.1021/ef050228d

Chen, L. Y., Bao, J. H., Kong, L., Combs, M., Nikolic, H. S., Fan, Z., \& Liu, K. L. (2016). The direct solid-solid reaction between coal char and iron-based oxygen carrier and its contribution to solid-fueled chemical looping combustion. Applied Energy, 184, 9-18. doi:10.1016/j.apenergy.2016.09.085

Cho, P., Mattisson, T., \& Lyngfelt, A. (2004). Comparison of iron-, nickel-, copper- and manganese-based oxygen carriers for chemicallooping combustion. Fuel, 83(9), 1215-1225. doi:10.1016/j.fuel.2003.11.013

Data, I. C. f. D., Selected Powder Diffraction Data for Education \& [and] Training: Search Manual and Data Cards. JCPDS: 1988.

Fan, L. S., Li, F. X., \& Ramkumar, S. (2008). Utilization of chemical looping strategy in coal gasification processes. Particuology, 6(3), 131-142. doi:10.1016/j.partic.2008.03.005

Genc, V. E., Altay, F. E., \& Uner, D. (2005). Testing molten metal oxide catalysts over structured ceramic substrates for diesel soot oxidation. Catalysis Today, 105(3-4), 537-543. doi:10.1016/j.cattod.2005.06.018

Jensen, J. O. (2003). Vibrational frequencies and structural determinations of $\mathrm{Pb} 6 \mathrm{O}(\mathrm{OH})(6)(4+)$. Journal of Molecular StructureTheochem, 635, 11-24. doi:10.1016/s0166-1280(03)00378-6

Jerndal, E., Leion, H., Axelsson, L., Ekvall, T., Hedberg, M., Johansson, K., . . . Lyngfelt, A. (2011). Using Low-Cost Iron-Based Materials as Oxygen Carriers for Chemical Looping Combustion. Oil \& Gas Science and Technology-Revue D Ifp Energies Nouvelles, 66(2), 235-248. doi:10.2516/ogst/2010030

Kanca, A. (2013). Characterization and reactivity studies for chemical loop gasification of high sulfur lignites. (PhD), Middle East Technical University.

Kanca, A., Dodd, M., Reimer, J. A., \& Uner, D. (2016). Following the structure and reactivity of Tuncbilek lignite during pyrolysis and hydrogenation. Fuel Processing Technology, 152, 266-273. doi:10.1016/j.fuproc.2016.06.014

Kanca, A., \& Uner, D. (2019). In situ and downstream sulfidation reactivity of $\mathrm{PbO}$ and $\mathrm{ZnO}$ during pyrolysis and hydrogenation of a high-sulfur lignite. International Journal of Hydrogen Energy, 44(34), 18827-18835. doi:10.1016/j.ijhydene.2018.10.041

Kim, H. R., Wang, D. W., Zeng, L., Bayham, S., Tong, A., Chung, E., . . Fan, L. S. (2013). Coal direct chemical looping combustion process: Design and operation of a 25-kW(th) sub-pilot unit. Fuel, 108, 370-384. doi:10.1016/j.fuel.2012.12.038

Ksepko, E., Babinski, P., Evdou, A., \& Nalbandian, L. (2016). Studies on the redox reaction kinetics of selected, naturally occurring oxygen carrier. Journal of Thermal Analysis and Calorimetry, 124(1), 137-150. doi:10.1007/s10973-015-5107-x

Ksepko, E., \& Labojko, G. (2014). Effective direct chemical looping coal combustion with bi-metallic Fe-Cu oxygen carriers studied using TG-MS techniques. Journal of Thermal Analysis and Calorimetry, 117(1), 151-162. doi:10.1007/s10973-014-3674-X

Ksepko, E., Siriwardane, R. V., Tian, H. J., Simonyi, T., \& Sciazko, M. (2010). Comparative Investigation on Chemical Looping Combustion of Coal-Derived Synthesis Gas containing H2S over Supported NiO Oxygen Carriers. Energy \& Fuels, 24(8), 42064214. doi:10.1021/ef100490m

Ksepko, E., Siriwardane, R. V., Tian, H. J., Simonyi, T., \& Sciazko, M. (2012). Effect of H2S on Chemical Looping Combustion of Coal-Derived Synthesis Gas over Fe-Mn Oxides Supported on Sepiolite, ZrO2, and Al2O3. Energy \& Fuels, 26(4), $2461-2472$. doi:10.1021/ef201441k

Larring, Y., Braley, C., Pishahang, M., Andreassen, K. A., \& Bredesen, R. (2015). Evaluation of a Mixed Fe-Mn Oxide System for Chemical Looping Combustion. Energy \& Fuels, 29(5), 3438-3445. doi:10.1021/acs.energyfuels.5b00048

Lopes, I., El Hassan, N., Guerba, H., Wallez, G., \& Davidson, A. (2006). Size-induced structural modifications affecting Co3O4 nanoparticles patterned in SBA-15 silicas. Chemistry of Materials, 18(25), 5826-5828. doi:10.1021/cm061630o

Matzen, M., Pinkerton, J., Wang, X. M., \& Demirel, Y. (2017). Use of natural ores as oxygen carriers in chemical looping combustion: A review. International Journal of Greenhouse Gas Control, 65, 1-14. doi:10.1016/j.ijggc.2017.08.008 
Sarafraz, M. M., Jafarian, M., Arjomandi, M., \& Nathan, G. J. (2018). Potential of molten lead oxide for liquid chemical looping gasification (LCLG): A thermochemical analysis. International Journal of Hydrogen Energy, 43(9), 4195-4210. doi:10.1016/j.ijhydene.2018.01.035

Shen, X. P., Miao, H. J., Zhao, H., \& Xu, Z. (2008). Synthesis, characterization and magnetic properties of Co3O4 nanotubes. Applied Physics a-Materials Science \& Processing, 91(1), 47-51. doi:10.1007/s00339-007-4361-6

Siriwardane, R., Tian, H. J., Richards, G., Simonyi, T., \& Poston, J. (2009). Chemical-Looping Combustion of Coal with Metal Oxide Oxygen Carriers. Energy \& Fuels, 23(8), 3885-3892. doi:10.1021/ef9001605

Siriwardane, R. V., Ksepko, E., Tian, H. J., Poston, J., Simonyi, T., \& Sciazko, M. (2013). Interaction of iron-copper mixed metal oxide oxygen carriers with simulated synthesis gas derived from steam gasification of coal. Applied Energy, 107, 111-123. doi:10.1016/j.apenergy.2013.01.063

Uner, D., Demirkol, M. K., \& Dernaika, B. (2005). A novel catalyst for diesel soot oxidation. Applied Catalysis B-Environmental, 61(34), 334-345. doi:10.1016/j.apcatb.2005.05.011

Velasco-Sarria, F. J., Forero, C. R., Adanez-Rubio, I., Abad, A., \& Adanez, J. (2018). Assessment of low-cost oxygen carrier in Southwestern Colombia, and its use in the in-situ gasification chemical looping combustion technology. Fuel, 218, 417-424. doi:10.1016/j.fuel.2017.11.078

Yung, M. M., Zhao, Z. K., Woods, M. P., \& Ozkan, U. S. (2008). Preferential oxidation of carbon monoxide on CoOx/ZrO2. Journal of Molecular Catalysis a-Chemical, 279(1), 1-9. doi:10.1016/j.molcata.2007.09.026

Zafar, Q., Mattisson, T., \& Gevert, B. (2005). Integrated hydrogen and power production with CO2 capture using chemical-looping reforming-redox reactivity of particles of $\mathrm{CuO}, \mathrm{Mn} 2 \mathrm{O} 3, \mathrm{NiO}$, and $\mathrm{Fe} 2 \mathrm{O} 3$ using $\mathrm{SiO} 2$ as a support. Industrial \& Engineering Chemistry Research, 44(10), 3485-3496. doi:10.1021/ie048978i 